\title{
Analysis of Electrochemical Porosity of Phosphatized \\ Coatings on Galvanized Steel Substrate
}

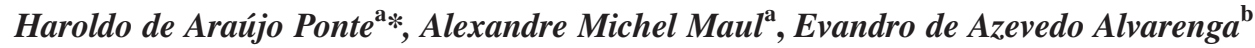 \\ ${ }^{a}$ Universidade Federal do Paraná, Departamento de Tecnologia Química, \\ Laboratório de Eletroquímica de Superfície e Corrosão-LESC, Centro Politécnico \\ C.P. 19011, 81531-990 Curitiba - PR, Brazil \\ ${ }^{\mathrm{b}}$ USIMINAS S.A., Centro de Pesquisa e Desenvolvimento \\ 35160-900 Ipatinga - MG, Brazil
}

Received: October, 22, 2001 Revised: August, 5, 2002

\begin{abstract}
This work refers to the application of a Voltammetric Anodic Dissolution (VAD) Technique in the analysis of coating discontinuities, focusing on pores and cracks that exposed the substrate. An evaluation was made of the influence of several parameters, such as the concentration of the passivation solution and sweep rate (SR), on the substrate passivation process and on the porosity indexes of tricationic phosphate coatings of $\mathrm{Fe} / \mathrm{Zn} / \mathrm{Mn}$. The phosphatization process used was a commercial tricationic $\mathrm{Fe} / \mathrm{Zn} / \mathrm{Mn}$ phosphate bath applied on a galvanized steel (GS) substrate. Once the best experimental conditions for the use of the VAD technique had been defined, the grain size and layer weight were related to porosity indexes. The porosity was found to show a tendency to decrease with increasing grain size. The VAD technique consists of the anodic polarization of the substrate/coating system and measurement of the charge density involved in the substrate passivation process. A quantitative porosity index was obtained by comparing the passivation charge density of the substrate without coating (standard passivation charge density) and the passivation charge of the coated substrate.
\end{abstract}

Keywords: porosity, coating discontinuities, phosphate, voltammetric anodic dissolution

\section{Introduction}

The corrosion resistance of the coating/substrate system is associated with the area of metal exposed through pores or coating discontinuities. Today, phosphate analyses are a part of corrosion tests carried out after painting and chemical tests on the untreated layer ${ }^{1}$.

The traditional methods to determine porosity rely on the observation of active pores (chemical tests with ferrocyanide or other aggressive solutions, hot water, electrographic and salt-spray tests). These procedures are, therefore, qualitative ones ${ }^{2}$. Because these techniques are based on the observation and counting of chemically marked spots, they are insensitive to small discontinuities and depend on subjective criteria. These limitations render the use of traditional methods useless to detect small cracks and pores $^{3}$.

In today's electrochemical tests, the analyzed sample operates as the anode in an electrochemical cell. This requires that the coating is kept inert in relation to the electrolyte during immersion in the passivation solution (chemical attack) and during anodic polarization ${ }^{4}$.

There are several variants of electrochemical tests to determine coating porosity, which are usually classified into three main groups ${ }^{5,6}$ :

- Corrosion potential measurements;

- Corrosion current measurements;

- Polarization resistance measurements;

- Coulometric measurements.

Corrosion potential measurements were first reported by Hoar ${ }^{7}$. This author observed that the potential of samples covered with tin changed when scratches of different sizes were applied to the sample. This technique is very simple. However, it presents limitations for the analysis of very large or very small areas of exposed substrate.

Soon after Hoar's first report, Evans ${ }^{8}$ proposed a simple 
method to measure the corrosion current ${ }^{8,9,10}$. He suggested that if the ratio between the cathodic area (the coating or an auxiliary electrode) and the anodic area (exposed substrate) was high enough, the corrosion current flowing through the cathode would be practically independent of the cathodic area but strongly dependent on the anodic one. Hence, the current could result in a porosity index.

Clarke and Britton applied the resistance polarization technique to study tin-nickel coatings on steel. This technique presented serious limitations for thin coating analyses, since the effect of the resistance inside pores became less significant ${ }^{4}$.

Typical porosity tests for phosphate coating analyses are the ferrocyanide test and the copper deposition test; however, electrochemical tests ensure better control of the test conditions ${ }^{11}$.

Weng et al. studied the porosity of zinc and manganese phosphate coatings ${ }^{12}$, using the polarization resistance technique and obtaining an average porosity of less than $1.5 \%$ for zinc and manganese coatings ${ }^{12}$.

In this work, the electrochemical Voltammetric Anodic Dissolution (VAD) technique ${ }^{11,13}$, in which the passivation charge of the substrate is measured, is used to determine the phosphate coating porosity of galvanized steel (GS) foils prepared under different phosphatization conditions. The advantages of this technique are the short analysis time (about $1 \mathrm{~min}$ ) and the fact that a calibration curve is unnecessary, requiring only the passivation standard charge (substrate with unitary porosity without coating).

\section{Materials and Methods}

The voltammetric anodic dissolution technique (VAD) used in this study consists of the anodic polarization of the substrate/coating system and measurement of the charge density involved in the substrate's passivation process.

A comparison of the passivation charge density of the substrate without coating (standard passivation charge density, $\left.Q_{\text {pass }}^{0}\right)$ and that of the coated substrate $\left(Q_{\text {pass }}\right)$ supplies the porosity, which is expressed by:

$$
\theta=\frac{Q_{\text {pass }}}{Q_{\text {pass }}^{0}}
$$

where: $q=$ porosity, fraction of the substrate's area exposed to the electrolyte;

$Q_{\text {pass }}^{0}=$ dissolution/passivation charge of the uncoated substrate;

$Q_{\text {pass }}=$ dissolution/passivation charge of the coated substrate.

The conditions needed to apply this technique are:

- The substrate must be devoid of chemical attack in the dissolution/passivation solution.

- The substrate must become passivated when anodically polarized.

- The coating must remain inert or present a slight and measurable reaction rate in the potential range in which the passivation process occurs ${ }^{1,13,14,15}$.

The most suitable experimental conditions (solution, solution concentration and sweep rate) for the application of the VAD technique were determined in this study. An evaluation of the porosity of a tricationic phosphate coating on galvanized steel was made prior to selecting the experimental conditions. The phosphate layers were obtained by applying five different phosphatization conditions.

All the reagents used in this study were of analytical grade and the solutions were kept at ambient temperature $\left(25^{\circ} \mathrm{C}\right)$. Distilled water was used to prepare solutions, material wash and cell wash. The foils were cleaned with acetone before the electrochemical procedures.

All the potentials were measured in relation to a saturated calomel electrode (SCE) and a three-electrode cell was used in the experiments. A platinum wire was used as a counter-electrode. The cell used here was built to fit plane electrodes. The exposed area of the working electrode was $1.23 \mathrm{~cm}^{2}$. The main equipment used in this work was a PAR, model 273A potentiostat/galvanostat coupled to a microcomputer with data acquisition software. Scanning Electron Microscopy (SEM) was used to analyze the samples' surface morphology.

The phosphatization conditions described below are dubbed hereinafter as PC-1, PC-2, PC-3, PC-4 and PC-5. Samples PC-1 to PC-4 were obtained by batch phosphatization, while sample PC-5 was obtained through a continuous process in a metal processing plant.

Degreasing was carried out using a 3\% concentration of a commercial product at $60{ }^{\circ} \mathrm{C}$ for $1.5 \mathrm{~min}$. The refining process was used to obtain phosphate grain size variations. In the PC- 1 condition, a concentration of $3 \mathrm{~g} / \mathrm{l}$ of a commercial product was used for $50 \mathrm{~s}$, and the same product was used for $10 \mathrm{~s}$ for the PC- 2 condition, but with a $0.3 \mathrm{~g} / \mathrm{l}$ concentration. A different commercial product with an $0.3 \mathrm{~g} / \mathrm{l}$ concentration was used for $5 \mathrm{~s}$ in the PC- 3 condition. The refining process was not used in the PC- 4 condition. The phosphatization process was common to all the conditions, using a commercial tricationic phosphatization $\left(\mathrm{Zn} / \mathrm{Fe} / \mathrm{Mn}\right.$ ) solution which was kept at $60{ }^{\circ} \mathrm{C}$ for 20 to $25 \mathrm{~s}$. The passivation process, applied to all the samples, employed a commercial product with $1 \mathrm{~g} / \mathrm{l}, \mathrm{pH}$ 4.3. The solution was kept at $60{ }^{\circ} \mathrm{C}$ for $1.5 \mathrm{~min}$. All the specimens were dried in hot air.

The PC-5 condition corresponded to a galvanized steel foil phosphatized by a continuous process at a metallurgical company. 


\section{Results and Discussion}

\subsection{Characterization of the Phosphate Layer}

The grain size was evaluated based on the average value obtained through eight different grain size analyses made on each side of the phosphatized galvanized foils (see Ta- ble 1). A slight dispersion was found between the grain size obtained for side A (front) and side B (back). Eight analyses were made of each face to determine the grain size. The layer weight is also shown in Table 1.

Figure 1 presents SEM micrographs showing the superficial state of the phosphate layer and variations according

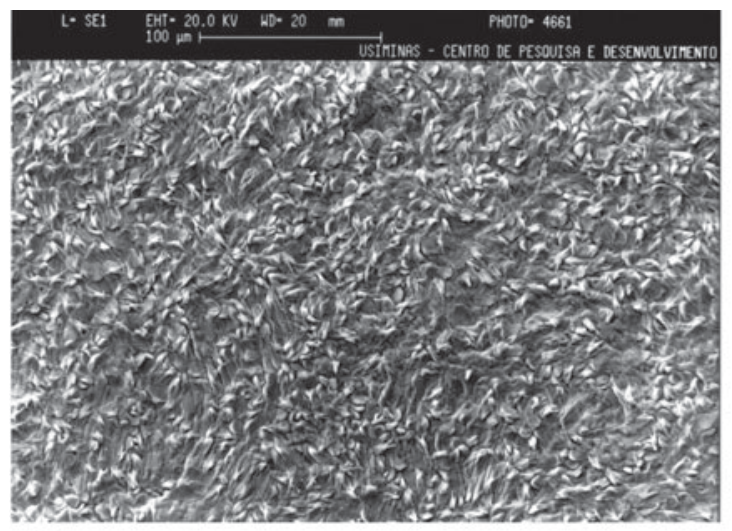

(a)

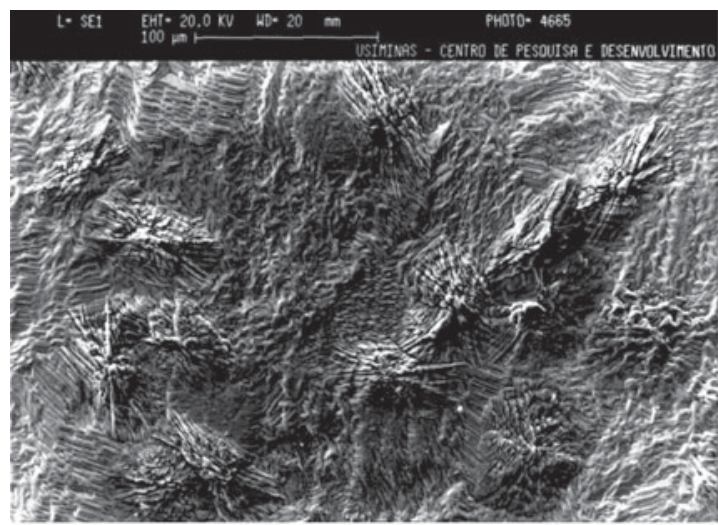

(b)

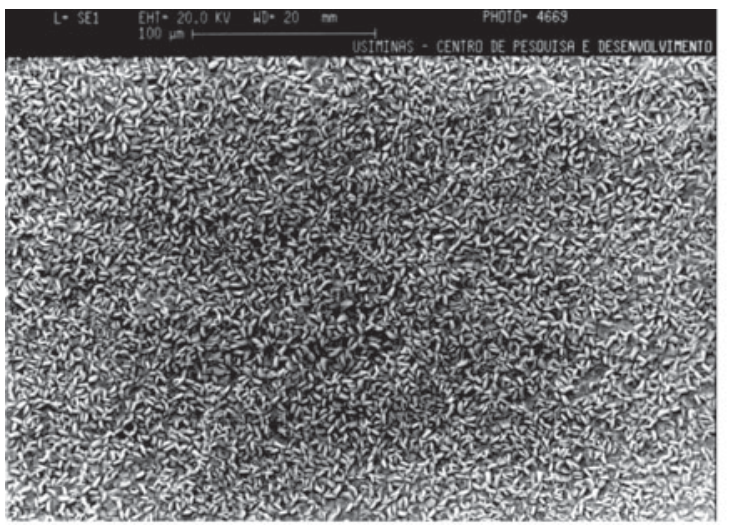

(c)
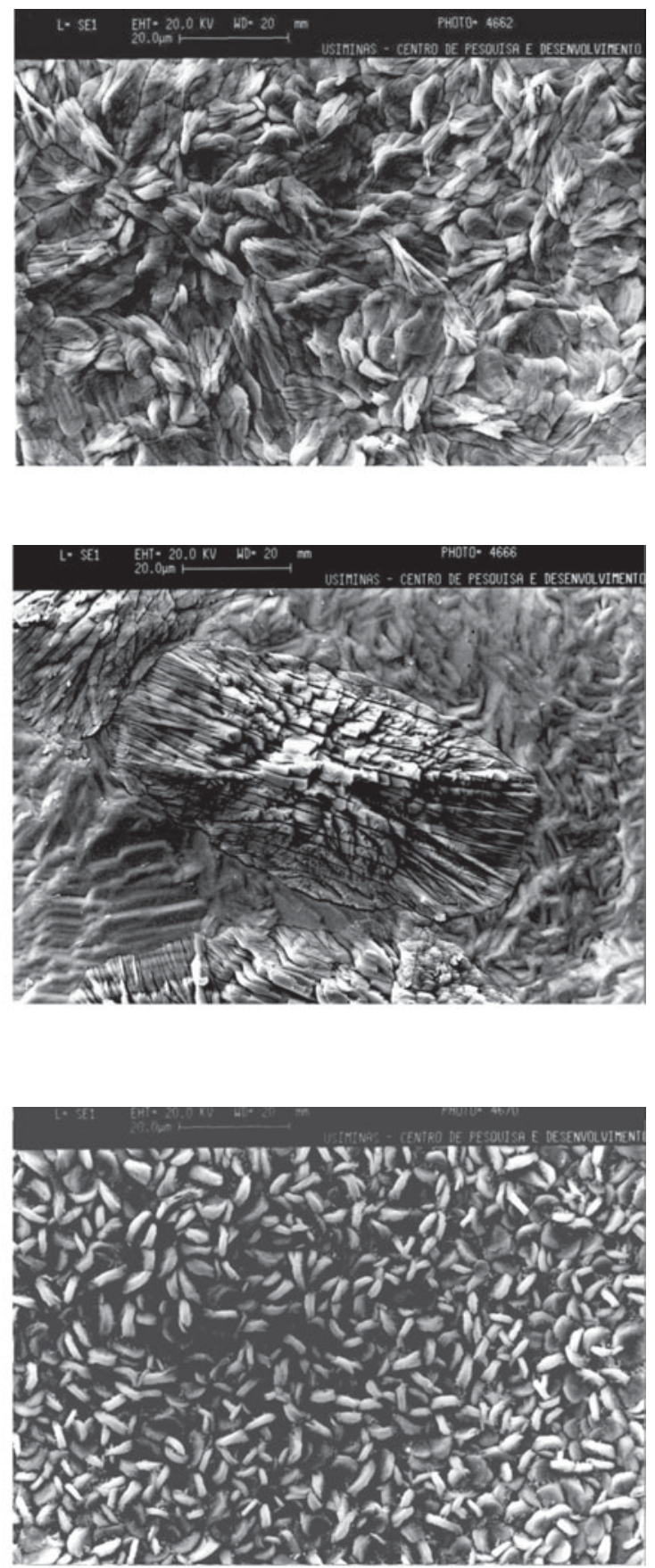

Figure 1. MEV micrographies of the phosphate layer surface, (a) PC-3, face A; (b) PC-4, face A; (c) PC-5, face A. 
Table 1. Grain size and weight of the phosphate layer for used phosphatization conditions.

\begin{tabular}{|c|c|c|c|c|c|c|c|c|c|c|c|}
\hline \multicolumn{12}{|c|}{ Phosphatization condition } \\
\hline \multirow{2}{*}{\multicolumn{2}{|c|}{ Face of the foil }} & \multicolumn{2}{|c|}{ PC-1 } & \multicolumn{2}{|c|}{ PC-2 } & \multicolumn{2}{|c|}{ PC-3 } & \multicolumn{2}{|c|}{ PC-4 } & \multicolumn{2}{|c|}{ PC-5 } \\
\hline & & A & $\mathrm{B}$ & $\mathrm{A}$ & B & $\mathrm{A}$ & $\mathrm{B}$ & A & $\mathrm{B}$ & A & $\mathrm{B}$ \\
\hline \multirow{2}{*}{ Grain Size $(\mu \mathrm{m})$} & Face average & 3.99 & 4.09 & 3.67 & 4.15 & 17.3 & 12.4 & 71.9 & 71.5 & 3.07 & 4.86 \\
\hline & Foil average & \multicolumn{2}{|c|}{4.04} & \multicolumn{2}{|c|}{3.91} & \multicolumn{2}{|c|}{14.9} & \multicolumn{2}{|c|}{71.7} & \multicolumn{2}{|c|}{6.96} \\
\hline \multicolumn{2}{|c|}{ Layer weight $\left(\mathrm{g} / \mathrm{m}^{2}\right)$} & \multicolumn{2}{|c|}{1.66} & \multicolumn{2}{|c|}{1.88} & \multicolumn{2}{|c|}{2.52} & \multicolumn{2}{|c|}{3.09} & \multicolumn{2}{|c|}{3.84} \\
\hline
\end{tabular}
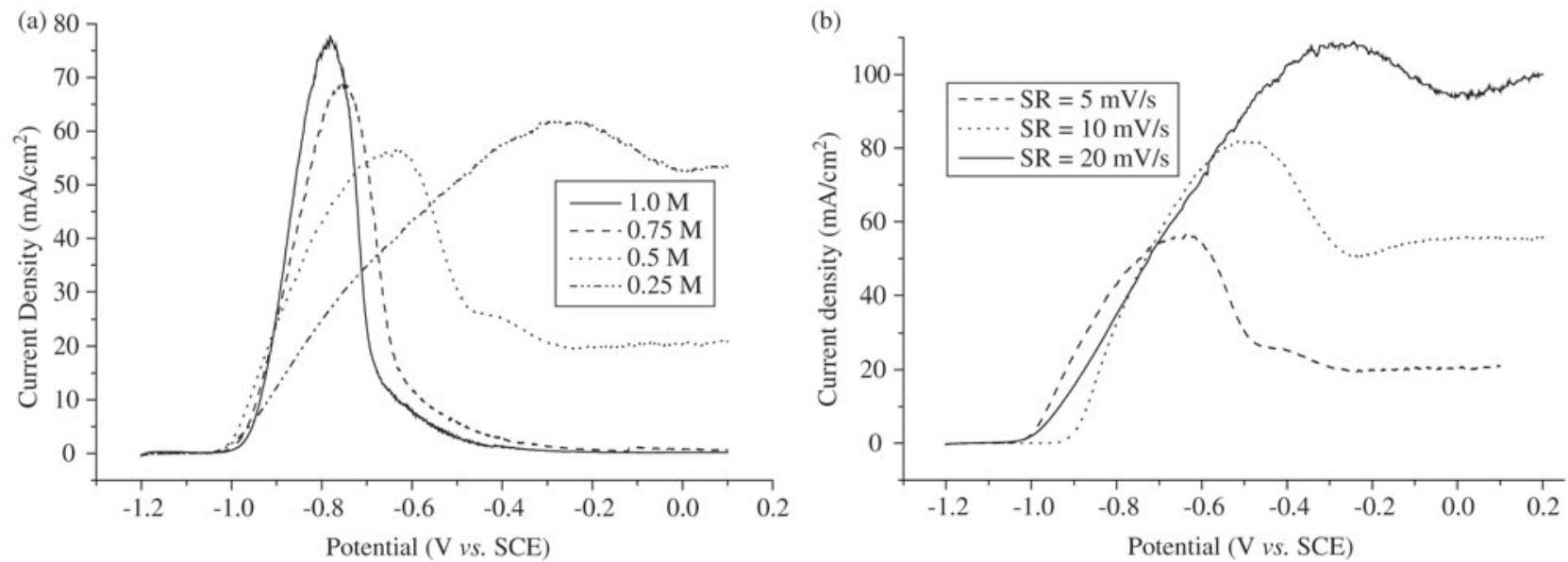

Figure 2. Influences of (a) potassium bicarbonate solution concentration and of (b) sweep rate (SR) on the zinc passivation voltammetries (pure zinc electrode).

to the phosphatization condition used. The PC-1, PC-2 and PC-3 phosphatization conditions show a similar morphology (needle-shaped crystals) common for batch processes but with different the crystal sizes. The PC-4 condition shows an aspect characteristic of the absence of the refining process, while condition PC-5 shows the morphological characteristic of phosphate layers obtained through continuous aspersion processes.

\subsection{Passivation Concentration Solution and Sweep Rate}

To elucidate the influence of the passivation concentration solution, four different concentrations were tested: $0.25 \mathrm{M} ; 0.5 \mathrm{M} ; 0.75 \mathrm{M}$ and 1.0 M, as given in Fig. 2a.

Based on Fig. 2a, it was found that increasing the concentration of the solution led to a clearer definition of the zinc dissolution/passivation peak, heightening the sensibility for the measurement of the charge density involved in the substrate passivation process.

An analysis of Fig. $2 b$ revealed that a lower sweep rate resulted in a better definition of the dissolution/passivation peak. According to these results, a $0.75 \mathrm{M}$ Potassium Bi- carbonate solution and a $10 \mathrm{mV} / \mathrm{s}$ sweep rate were selected to take the voltammetric measurements.

Two characteristics peaks were found in the steel voltammetry, probably associated with oxidation reactions of iron to $\mathrm{Fe}^{2+}$ and $\mathrm{Fe}^{3+}$ (Fig. 3a). In Fig. 3a, for the phosphatized steel case, only a small peak was visible, corresponding to reactions through the phosphate pores and cracks discussed earlier herein.

A description is given below of the steel foils used in this study, which hereinafter are referred to as steel - bare 1020 steel foil; galvanized steel (GS) - 1020 steel foil subjected to galvanization; phosphatized steel - 1020 steel foil subjected to phosphatization (without a zinc interlayer) and galvanized phosphatized steel-galvanized steel subjected to phosphatization.

In regard to the electrochemical behavior of the galvanized steel foil, it was observed that the passivation process started at a potential of around $-950 \mathrm{mV}$ (vs. SCE), as shown in Fig. 3b.

A comparison of the charges involved in the galvanized steel passivation process (Fig. 3b) and the charges involved 

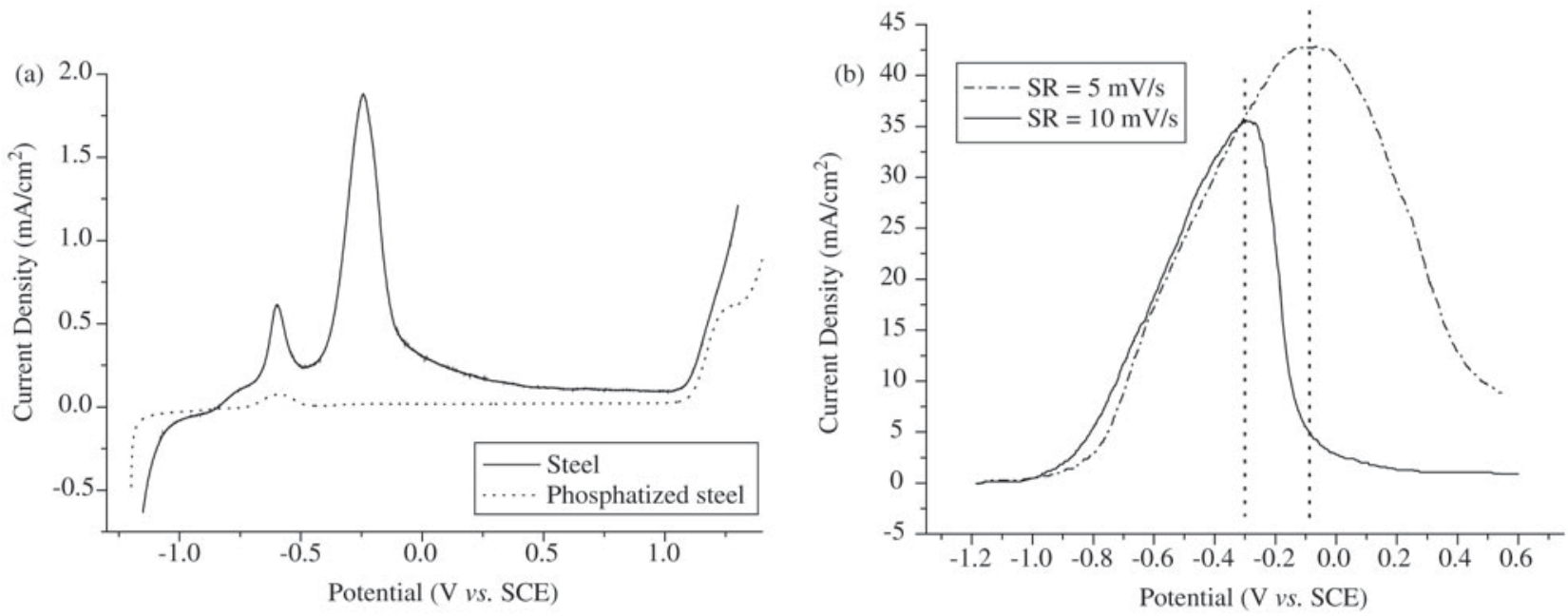

Figure 3. (a) Voltammetries for the steel and for phosphatized steel, $\mathrm{SR}=5 \mathrm{mV} / \mathrm{s}$, (b) Voltammetries for galvanized steel, $\mathrm{SR}=5$ and 10 $\mathrm{mV} / \mathrm{s}$; Solution: $0.75 \mathrm{M} \mathrm{KHCO}_{3}$.

in the passivation of the phosphatized steel (Fig. 3a), in the potential range of -1000 to $-300 \mathrm{mV}$ ( $v s$. SCE), led us to conclude that the phosphate layer did not react significantly with the dissolution/passivation solution during anodic polarization.

The dotted lines in Fig. $3 \mathrm{~b}$ indicate the passivation curve peaks for the two different sweep rates used. The charge density used to calculate the porosity corresponds to the area under the curve up to the passivation peak (half peak charges).

\subsection{Passivation Charge Density Determination}

The value of the standard passivation charge density $\left(Q_{\text {pass }}^{0}\right)$ involved in the passivation process of galvanized steel foil without a phosphatized layer (Fig. 3b) was calculated a $1.906 \mathrm{mC} / \mathrm{cm}^{2}$ for a sweep rate of $10 \mathrm{mV} / \mathrm{s}$.

After selecting the experimental conditions, i.e., passivation solution, range of potentials for the passivation process, and standard dissolution/passivation charge for the uncoated substrate, the phosphate porosity was determined. Voltammetric anodic polarization measurements were taken for each phosphatization condition (PC-1 to PC-5, described in section 2) and the passivation charge of the coated substrate, $\mathrm{Q}_{\text {pass. }}$ was calculated. The coating porosity index for each of these phosphatization conditions was then determined, based on the $Q_{\text {pass }}$ and Eq. 1 .

\subsection{Determination of Porosity}

Reference Fig. 4 presents the behavior of the galvanized sample under phosphatization condition PC-5, revealing a well-defined passivation peak. This behavior indicates a

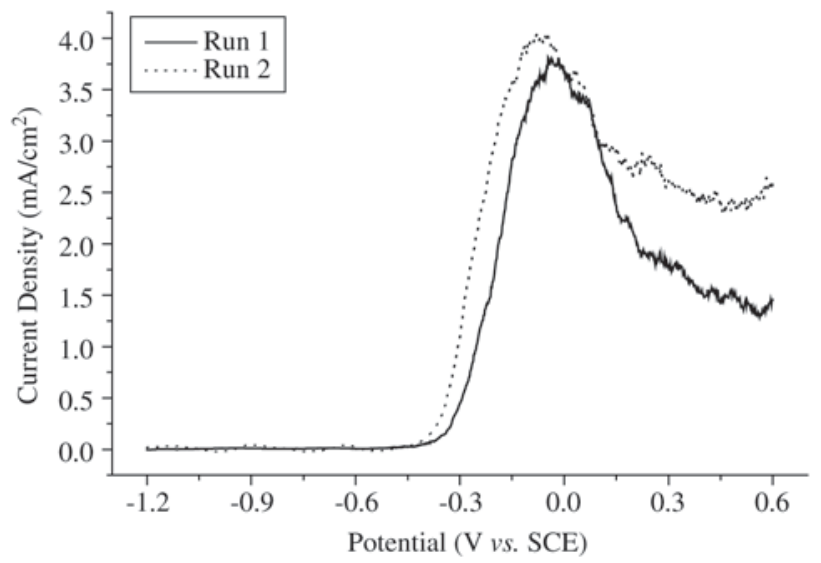

Figure 4. Voltammetries for galvanized and phosphatized steel foil, Phosphatization condition = PC-5, Solution: $0.75 \mathrm{M} \mathrm{KHCO}_{3}$, $\mathrm{SR}=10 \mathrm{mV} / \mathrm{s}$.

coating with little porosity. All the other measurements for PC-1, PC-2 and PC-3, which are not shown herein, revealed a similar behavior. Due to its peculiar conditions of grain size and morphology, PC-4 presented incoherent results not discussed here.

A comparison of Fig. 4 and Fig. 3b shows a displacement in the potential at which the passivation process occurs. This displacement occurs at a potential of about $600 \mathrm{mV}$ in the anodic direction and may be attributed to a change in the electrochemical behavior of zinc resulting from the phosphatization process or due to an ohmic drop caused by the coating. 
Comparing the different voltammetries (Fig. 5) for phosphatization conditions PC-1, PC-2, PC-3 and PC-5 showed, as mentioned earlier, a potential displacement for phosphatization condition $\mathrm{PC}-5$ in relation to phosphatization conditions PC-1, PC-2 and PC-3. This displacement may have originated from modifications in the electrochemical characteristics of the substrate/coating system caused by variations in the phosphatization process.

Some voltammetries for galvanized steel, phosphatized steel, and phosphatized galvanized steel under the PC-1, PC-4 and PC-5 conditions given in Fig. 6 show the same potential displacement, already observed in the passivation process, between the galvanized steel foil and the galva-

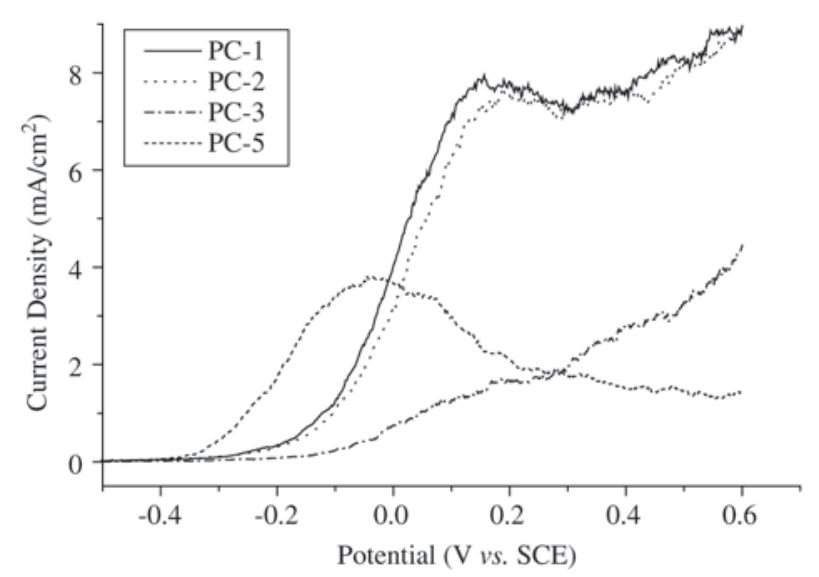

Figure 5. Voltammetries for phosphatized galvanized steel foil, Phosphatization conditions: PC-1, PC-2, PC-3 and PC-5, Solution: $0.75 \mathrm{M} \mathrm{KHCO}_{3}, \mathrm{SR}=10 \mathrm{mV} / \mathrm{s}$.

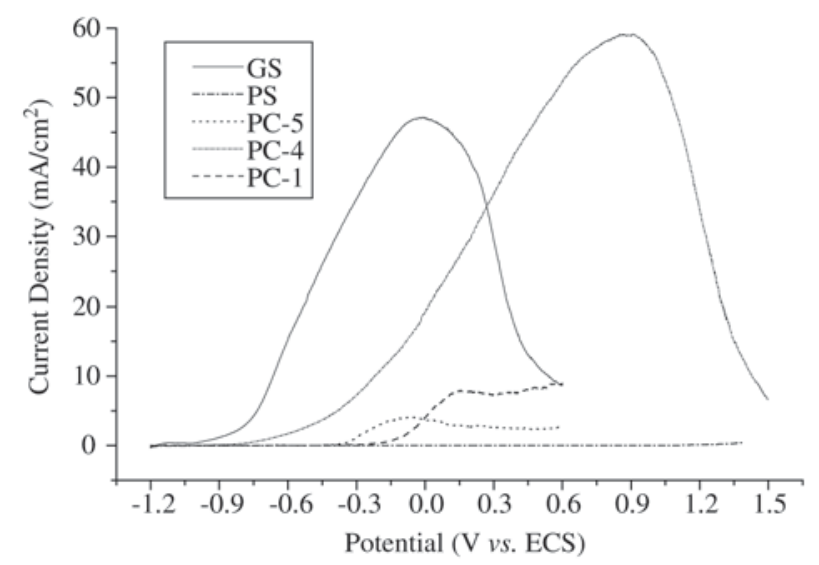

Figure 6. Comparison among the voltammetries for galvanized steel, phosphatized steel (without zinc) and galvanized phosphatized steel, Phosphatization conditions: PC-1, PC-4 and PC-5, Solution: $0.75 \mathrm{M} \mathrm{KHCO}_{3}, \mathrm{SR}=10 \mathrm{mV} / \mathrm{s}$. nized and phosphatized steel foil. The galvanized and phosphatized foils displayed a cathodic behavior in relation to the galvanized foils.

Figure 6 shows a typical behavior for foils processed under the phosphatization condition PC-4. In this condition, the measurements indicated severe exposure of the substrate and porosity indexes greater than $100 \%$, probably associated with substrate dissolution occurring during the phosphatization process. This substrate dissolution process increases the superficial rugosity of the zinc substrate, giving incorrect values for passivation charge density. For this reason, this condition will be disregarded in future analyses.

The porosity indexes were determined for each phosphatization condition using the above-mentioned procedure and equation (see Table 2). The porosity for each phosphatization condition was then plotted based on these indexes, the average grain size and the weight of the phosphate layer (see Table 1).

A reveals a tendency for the porosity level of the phosphate layer to decline as grain size increases. This behavior indicates a correlation between the porosity level and the grain size that allows the porosity level for phosphate coatings or phosphate grain size to be estimated by interpolating values at the resulting curve. The phosphatization condition PC-4, which corresponded to large grains (See Table 1), displayed extremely high porosity indexes and was not considered herein.

Plotting the porosity and the layer weight (Fig. 7b) showed an inversion of the porosity value for foils processed under phosphatization conditions PC-5 and PC-3 compared to Fig. 7a. This inversion may be evidence of the morphological influence of the grain's shape. The morphology of these grains is shown in the micrographs presented in Fig. 1, where the phosphate crystals obtained under phosphatization condition PC-3 display a flatter structure (needle-shaped), favoring a lesser porosity than the structure obtained for grains under condition PC-5 (disc-shaped).

Table 2. Values of areas until the passivation peak, passivation charge density and porosity indexes for the analyzed foils, $\mathrm{SR}=10 \mathrm{mV} / \mathrm{s}$.

\begin{tabular}{lcccc}
\hline Foil & $\begin{array}{c}\text { Number of } \\
\text { measures }\end{array}$ & $\begin{array}{c}\text { Area until } \\
\text { peak* }\left(\mathrm{cm}^{2}\right)\end{array}$ & $\begin{array}{c}\text { Passivation charge } \\
\text { density* }\left(\mathrm{mC} / \mathrm{cm}^{2}\right)\end{array}$ & $\begin{array}{c}\text { Porosity } \\
\text { Index }(\%)\end{array}$ \\
\hline GS & 2 & 19.06 & 1.906 & 1 \\
PC-1 & 3 & 1.108 & 0.111 & 4.98 \\
PC-2 & 3 & 1.197 & 0.197 & 5.38 \\
PC-3 & 3 & 0.442 & 0.044 & 1.99 \\
PC-5 & 2 & 0.748 & 0.075 & 3.36 \\
\hline
\end{tabular}

* Averaged values. 

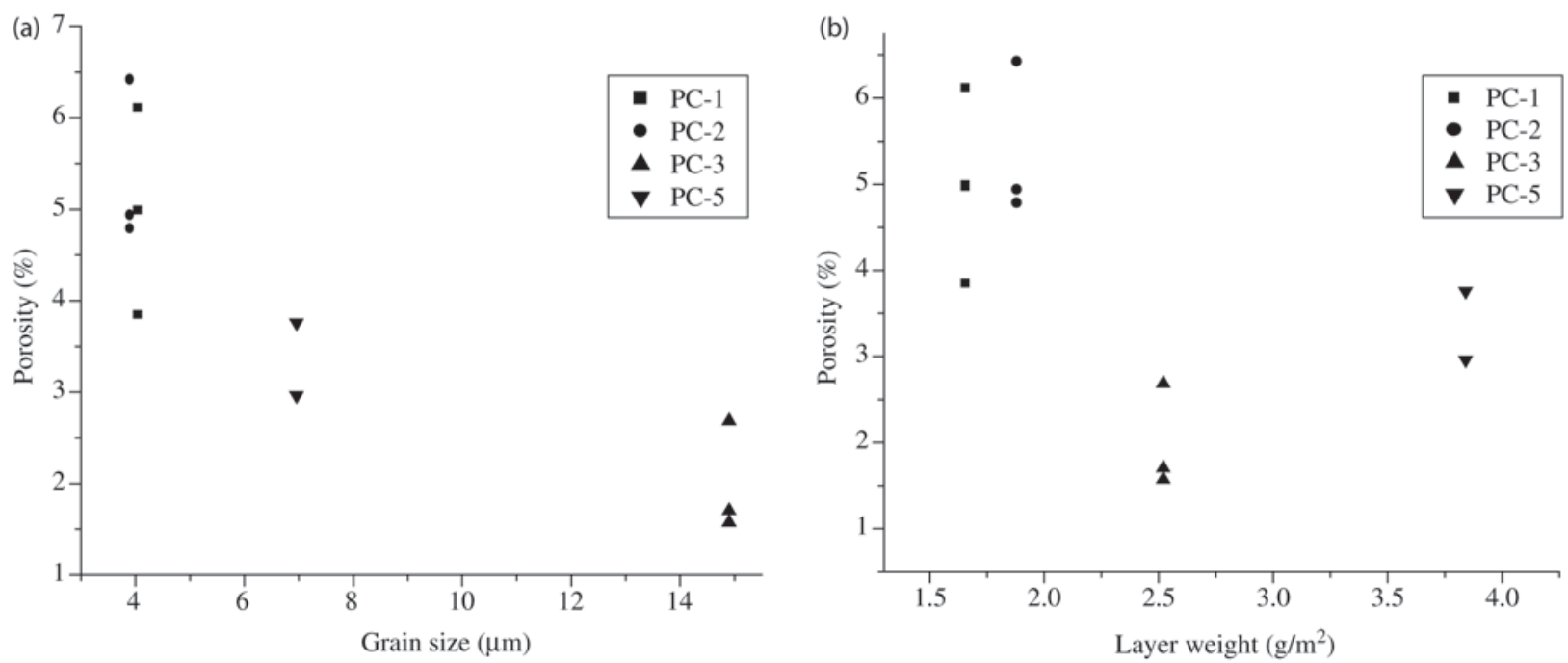

Figure 7. Variation of the porosity with a) the grain size and b) the weight of the phosphate layer, Solution: $0.75 \mathrm{M} \mathrm{KHCO}_{3}, \mathrm{SR}=10 \mathrm{mV} / \mathrm{s}$.

\section{Conclusions}

The experimental conditions fit the previous behavior established for the application of the voltammetric anodic dissolution - VAD technique, in other words,

- The substrate suffered no chemical attack in the dissolution/passivation solution;

- The substrate became passivated when anodically polarized;

- The coating remained inert in the potential range in which the passivation process occurred.

The VAD technique used in this study showed a good level of sensibility, allowing for phosphate coating porosity on galvanized steel to be determined for grain sizes and layer weights varying in a range of $1 \%$.

The degree of phosphate porosity or grain size under different phosphate processing conditions was also estimated by interpolating values of the results obtained.

\section{Acknowledgements}

This study was supported by Usiminas S.A., which supplied steel foils and resources for the development of the project, and by Chemetall S.A., which supplied phosphatization baths and phosphatized foils for the various conditions analyzed. Finally, we would like to thank the Brazilian research funding institution CAPES and the Brazilian National Petroleum Agency - ANP for their financial support.

\section{References}

1. Carlos, I.A. D.Sc. Thesis, Universidade Federal de São Carlos, USP-IFQSC, 1990.
2. Julve, E. Determinación de la porosidad de los recubrimientos metálicos obtenidos por vía electrolítica: 1. Métodos utilizados en talleres galvanotécnicos, Pintura y Acabados, p. 80-86, 1986.

3. Roos, J.R.; Celis, J.P.; Chonglun, Fan. Coulometric measurement of the porosity in thin nickel coatings, $J$. Electrochem. Soc., v. 137, n. 04, p. 1096-1099, 1990.

4. Leisner, P.; Benzon, M.E. Porosity measurements on coatings, Trans. Inst. Metal Finishing, v. 75, n. 2, p. 88-92, 1997.

5. Notter, I.M.; Gabe, D.R. The electrochemical thyocianate porosity test for tinplate, Trans. Inst. Metal Finishing, v. 68, p. 59-94, 1990.

6. Notter, I.M.; Gabe, D.R. Polarization resistance methods for measurement of the porosity of thin metal coatings, Corrosion Science, v. 34, n. 5, p. 851-870, 1993.

7. Hoar, T.P. The electrochemistry of protective metallic coatings, J. Electrodepositors' Tech. Soc., v. 14, p. 3346, 1938.

8. Evans, U.R.; Shome, S.C. Studies in the discontinuities in electrodeposited metallic coatings - Part I, J. Electrodepositors'Tech. Soc., v. 26, p. 137-160, 1950.

9. Evans, U.R.; Shome, S.C. Studies in the discontinuities in electrodeposited metallic coatings - Part II, J. Electrodepositors' Tech. Soc., v. 27, p. 45-64, 1951.

10. Evans, U.R.; Shome, S.C. Studies in the discontinuities in electrodeposited metallic coatings - Part III, $J$. Electrodepositors'Tech. Soc., v. 27, p. 65-74, 1951.

11. Losch, A.; Schultze, J.W.; Speckman, H.-D. A new electrochemical method for the determination of the free surface of phosphate layers, Anais do EUROCORR'91, Budapeste, p. 413-418, 1991. 
12. Weng, D.; Jokiel, P.; Uebleis, A.; Bohemi, H. Corrosion and protection characteristics of zinc and manganese coatings, Surface \& Coatings Technology, v. 88, p. 147156, 1996.

13. Ponte, H.A.; Maul, A.M. Análise por técnica eletroquímica da porosidade de revestimentos sobre superfícies metálicas. Anais do XV Congresso Brasileiro de Engenharia Mecânica, COBEM 1999, Águas de Lindóia, SP, CD-Rom, 1999.
14. Ponte, H.A.; Maul, A.M. Análise quantitativa da porosidade de eletrodepósitos por dissolução anódica voltammetric, I - Eletrodepósitos de níquel sobre cobre, Anais do Interfinish Latino Americano, EBRATS 97, São Paulo, SP, CD-Rom, 1997.

15. Maul, A.M. M.Sc. Thesis, Análise por técnica eletroquímica da porosidade de revestimentos sobre superfícies metálicas, Universidade Federal of Paraná, PIPE, 2001. 